\title{
Uporaba neonikotinoida i praćenje njihovih rezidua u medonosnim pčelama i pčelinjim proizvodima
}

\author{
Damir Pavliček*, Nina Bilandžić, Ivana Tlak Gajger i \\ Marija Denžić Lugomer
}

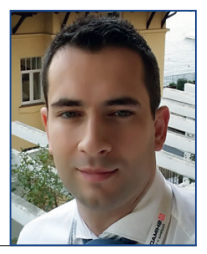

\section{Sažetak}

Uporaba pesticida na poljoprivrednim usjevima često se zbog otrovanja povezuje $s$ masovnim ugibanjem ili slabljenjem pčelinjih zajednica. Pesticidi iz skupine neonikotinoida, zahvaljujući svojim karakteristikama visoke toksičnosti za kukce, odnosno niske za kralježnjake, visoke učinkovitosti i sistemične aktivnosti u biljkama, postala je najupotrebljivija vrsta insekticida $u$ posljednjih 20 godina. U osnovnoj strukturi ovi pesticidi sadrže nitrometilensku, nitroiminsku ili cijanoiminsku funkcionalnu skupinu, a glavni predstavnik je imidakloprid, poslije glifosata drugi najprodavaniji pesticid na svijetu,. Prema mehanizmu djelovanja, neonikotinoidi su agonisti postsinaptičkog nikotin acetilkolinskog receptora u centralnom živčanom sustavu kukaca, gdje blokadom prijenosa signala izazivaju dezorijentaciju, paralizu, ali i njihovo uginuće. Rezidue neonikotinoida prisutne su i $\mathrm{u}$ peludu i u nektaru biljaka, što je glavni izvor prirodne

hrane za pčele, koje ih skupljačkom aktivnošću donose i pohranjuju u košnicama. Sve veći broj istraživanja opisuje kako koncentracije ovih insekticida negativno utječu na ponašanje i zdravlje zajednica medonosnih pčela. Stoga je Europska Komisija na temelju izvješća o procjeni štetnosti ovih pesticida u protekle tri godine zabranila osim u staklenicima uporabu klotianidina, imidakloprida, tiametoksama i tiakloprida na svim otvorenim površinama u zemljama članicama Europske unije. $\mathrm{U}$ ovom preglednom radu, osim glavnih karakteristika neonikotinoida, dan je uvid u razvoj i implementaciju pouzdanih analitičkih metoda za određivanje njihovih rezidua $u$ pčelama i pčelinjim proizvodima, kao i izazov koji pritom predstavlja kompleksnost matrica zbog prisutnosti voska, proteina te drugih interferirajućih tvari.

Ključne riječi: neonikotinoidi, medonosna pčela, otrovnost, rezidue

Damir PAVLIČEK*, mag.chem., (dopisni autor, e-mail: pavlicek.vzk@veinst.hr), Hrvatski veterinarski institut, Veterinarski zavod Križevci, Hrvatska; dr. sc. Nina BILANDŽIĆ, dipl. ing. preh. tehnol., znanstvena savjetnica, Hrvatski veterinarski institut Zagreb, Hrvatska; dr. sc. Ivana TLAK GAJGER, dr. med. vet., redovita profesorica, Veterinarski fakultet Sveučilišta u Zagrebu, Hrvatska; Marija DENŽIĆ LUGOMER, dipl. ing. kemije, Hrvatski veterinarski institut, Veterinarski zavod Križevci, Hrvatska 


\section{Uvod}

Kontinuirani porast svjetske populacije uzrok je velikih promjena $u$ procesu poljoprivredne proizvodnje zbog sve veće potrebe stanovništva za hranom, ali i zadovoljavanje propisanih standarda njene kvalitete. Pesticidi se koriste kao dio suvremenih poljoprivrednih načela zaštite poljoprivrednih nasada od štetnika. Pesticidi su toksične tvari koje selektivno suzbijaju štetne organizme, ali zbog uočenog nepovoljnog djelovanja i na neciljane biološke sustave i organizme, njihova toksičnost je vrlo opsežno proučavana (Abdollahi i sur., 2004., Lushchak i sur., 2018.). Iako rezultati toksikoloških istraživanja upućuju na oksidativan stres kao mogući način njihovog djelovanja, precizni mehanizmi putem kojih pesticidi djeluju na stanični metabolizam u ljudi još uvijek nisu u potpunosti razjašnjeni. Toksični učinak obično ovisi o kemijskoj strukturi pesticida, dozi i vremenu izloženosti, ali u zaključcima pojedinih istraživanja povezuje ih se s regulacijom apoptoze $\mathrm{i}$ redoks signalizacijom (Raszewski i sur., 2015., Jabłońska-Trypuć, 2017.).

Pesticidi se prema svojoj namjeni mogu podijeliti $u$ nekoliko skupina, no bilo da se radi o insekticidima, herbicidima ili nekoj trećoj podvrsti ovih kemijskih tvari, njihova proširena uporaba rezultira onečišćenjem prirodnih ekosustava (biljni i životinjski svijet, podzemne, površinske i izvorske vode, tlo, zrak). Shodno tome, na udaru su i pčele, kukci zaslužni za oprašivanje oko 80 \% biljaka cvjetnica i koji zajedno s drugim kukcima, oprašuju više od $70 \%$ usjeva koji čine hranu za ljude. Zaslužne su i za očuvanje bioraznolikosti samoniklih biljaka u prirodi, a danas su ugroženije nego ikada. Uz niz uzroka ugibanja s kojima se susreću (bolesti, nedostatci prirodne hrane, smanjivanje površina prirodnog okoliša) pa se stoga uporabi štetnih pesticida pridaje sve veća uloga u velikim gubitcima pčelinjih zajednica diljem svijeta (Johnson i sur., 2010., Potts i sur., 2010.).

Poseban naglasak pridaje se pesticidima iz skupine neonikotinoida, relativno novijoj skupini sistemskih insekticida koju karakterizira dobra učinkovitost pri zaštiti poljoprivrednih kultura od štetnika. Iako su 1990-tih godina svjetskim tržištem insekticida dominirale najvažnije kemijske klase spojeva (karbamati, organofosfati i piretroidi), danas neonikotinoidi zauzimaju gotovo trećinu tržišta, pri čemu je imidakloprid najprodavaniji insekticid ili iza glifosata drugi najprodavaniji pesticid, s registriranom uporabom u više od 120 zemalja (Jeschke i sur., 2011.). Karakteristike zbog kojih su ovi spojevi doživjeli golem tržišni uspjeh svakako je široko područje učinkovitosti, sistemsko i translaminarno djelovanje, izražena rezidualna aktivnost i jedinstven mehanizam djelovanja. Usprkos prvotnim uvjerenjima kako su neonikotinoidi slabo otrovni za sisavce, sve je više dokaza o raznim toksičnim učincima ovih tvari na životinje i ljude (Phua i sur., 2009., Lonare i sur., 2014.). Najpoznatiji primjer otrovanja korisnih kukaca neonikotinoidima zabilježen je u južnoj Bavarskoj u travnju 2008. godine kada je unutar dva tjedna uginulo 11 500 pčelinjih zajednica (Stokstad, 2013.). Ustvrđeno je kako je uzrok katastrofe onečišćena prašina sa sjemenskog kukuruza tretiranog klotianidinom, pesticidom iz skupine neonikotinoida, zbog velike greške tvrtke koja je proizvodila sjeme, a nekontrolirano širila prilikom proljetne sjetve, a pritom nije upotrijebila tvari za vezanje pesticida i zrna. Iako se radilo o izdvojenom slučaju, njemačka je vlada reagirala i zabranila tretiranje kukuruza i još nekoliko drugih žitarica klotianidinom. Godinu dana kasnije, Francuska je nakon što su pčelari 
zaključili kako je otrovanje prouzročilo uginuće trećine njihovih pčelinjih zajednica uvela zabranu uporabe imidakloprida na suncokretu.

Nakon objavljivanja brojnih rezultata istraživanja koji su potvrdili rizično i štetno djelovanje neonikotinoida na pčelarstvo i opravdano postojanje rizika za pčele (Chauzat i sur., 2009., Krupke i sur., 2012.). Europska je agencija za sigurnost hrane (EFSA) 2013. godine objavila sveobuhvatno istraživanje radi ustvrđivanja stvarne opasnosti primjene ovihinsekticida, čijisu rezultatibiliosnova za privremeno ograničavanje uporabe tri aktivne tvari za koje je utvrđen visoki rizik za pčele. Uredbom Komisije (EZ) br. 485/2013 ustvrđeno je kako se klotianidin, imidakloprid i tiametoksam više ne smiju koristiti ili se dopušta njihova uporaba tek nakon cvatnje nasada biljaka samo za industrijsku primjenu, a u nekim kulturama za zaštitu sjemena, zemljišta ili folijarni tretman (EC, 2013.). Nakon donošenja ovih odluka o ograničenjima proizvodnje, prometa i uporabe nekih neonikotinoida zabilježene su uglavnom pozitivne reakcije, posebno iz ekoloških organizacija i udruženja pčelara. Međutim, proizvođači fitofarmaceutskih sredstava i dio poljoprivrednika zbog otežane provedbe zaštite bilja i usjeva ovakvu su odluku ocijenili neprikladnom. $\mathrm{Na}$ temelju daljnjih istraživanja utjecaja neonikotinoida na pčele i ostale korisne kukce oprašivače, koja su potvrdila veliku štetnost ovih spojeva za njihovo zdravlje, 27. travnja 2018. godine Stalni odbor za biljke, životinje, hranu i hranu za životinje donio je odluku kojom se u potpunosti zabranjuje uporaba klotianidina, imidakloprida i tiametoksama na svim otvorenim površinama, uz izuzetak staklenika, u zemljama članicama Europske unije (EC, 2018.a, 2018.b, 2018.c). EFSA je početkom 2019. godine objavila izvješće o procjeni štetnosti pesticida tiakloprida $(E C, 2019$.) temeljem kojeg je 03. veljače 2020. godine odlučeno kako i taj predstavnik neonikotinoida neće dobiti daljnje odobrenje za uporabu na području Europske unije. U slučaju acetamiprida ustvrđen nizak rizik za pčele i obnovljeno je odobrenje do 28. veljače 2033. godine (EC, 2018.d).

Iako zabrana najčešće korištenih neonikotinoida predstavlja važan korak za preokretanje pada populacije pčela $\mathrm{u}$ Europi i dalje se vode brojne rasprave oko uporabe ovih tvari i u ne postojanju alternative koja bi pokazala jednaku djelotvornost za brojne kombinacije usjeva i štetnika. Stoga postoje sumnje kako određeni broj poljoprivrednika i dalje koristi zabranjene tvari uvozom istih iz zemalja koje nisu članice EU i gdje su ovi proizvodi i dalje dostupni u slobodnoj prodaji.

Kako bi se zaštitila bioraznolikost i zdravlje ljudi vrlo je bitno pratiti rezidue insekticida rabljenih $\mathrm{u}$ poljoprivrednoj proizvodnji. Iz tog razloga razvijaju se visokoosjetljive i selektivne analitičke metode za određivanje niskih koncentracija rezidua neonikotinoida koji su uneseni u košnice na ili u tijelu pčela skupljačica i u pčelinjim proizvodima.

\section{Razvoj i kemijska struktura neonikotinoida}

Već stoljećima, poljoprivrednici upotrebljavaju vodene ekstrakte duhana s visokim koncentracijama nikotina za zaštitu poljoprivrednih usjeva od raznih štetnih kukaca. Sedamdesetih godina 20. stoljeća objavljena su prva znanstvena istraživanja i razvoj insekticida na bazi nikotina koji se nazivaju neonikotinoidi. Američki kemičar Henry Feuer sintetizirao je spoj 2-[dibrom(nitro)metil]-3-metilpiridin $\mathrm{s}$ insekticidnim djelovanjem na muhe i štetnike graška. To je bio prekursor za sintezu (E/Z)-2-nitrometilen-1,3thiazinana, poznatijeg kao nitiazin, nitrometilenskog neonikotinoidnog 
insekticida koji je učinkovito djelovao protiv kukuruzne uši i pokazivao nisku toksičnost za sisavce, ali zbog nedovoljne fotokemijske stabilnosti, što otežava široku primjenu u poljoprivredi, nikada nije komercijaliziran (Majdančić i sur., 2017.). Zamjenom nitrometilenske skupine $\mathrm{s}$ fotostabilnom nitroiminskom skupinom, tvrtka Bayer CropScience 1985. godine sintetizirala je spoj imidakloprid ([1-(6-kloro-3-piridilmetil)N-nitroimidazolidin-2-ilidenamin]), prvi komercijalan neonikotinoid koji se odlikuje visokom insekticidnom aktivnošću, niskom postojanosti u tlu i niskom toksičnosti u sisavaca. Nakon registracije imidakloprida 1992. godine, kroz sljedećih 10 godina još je šest neonikotinoida se pojavilo na tržištu acetamiprid 1995. god., nitenpiram 1995. god., tiametoksam 1998. god., tiakloprid 2000. god., klotianidin 2001. god. i dinotefuran 2002. god. (Slika 1.), što čini neonikotinoide najbrže rastućom klasom insekticida.

Prema kemijskoj strukturi neonikotinoidi se mogu razvrstati na molekule s ravnolančanom strukturom (acetamiprid, dinotefuran, klotianidin i nitenpiram) i molekule s heterocikličkom strukturom građenom od peteročlanih i šesteročlanih prstenova - imidakloprid, tiakloprid i tiametoksam (Iwasa i sur., 2004.). Često se navodi podjela na $N$-nitrogvanidine (imidakloprid, tiametoksam, klotianidin i dinotefuran), nitrometilene (nitenpiram) i $N$-cijanoamidine (acetamiprid), a još se spominje kako imidakloprid, nitenpiram, acetamiprid i tiakloprid veže zajednički

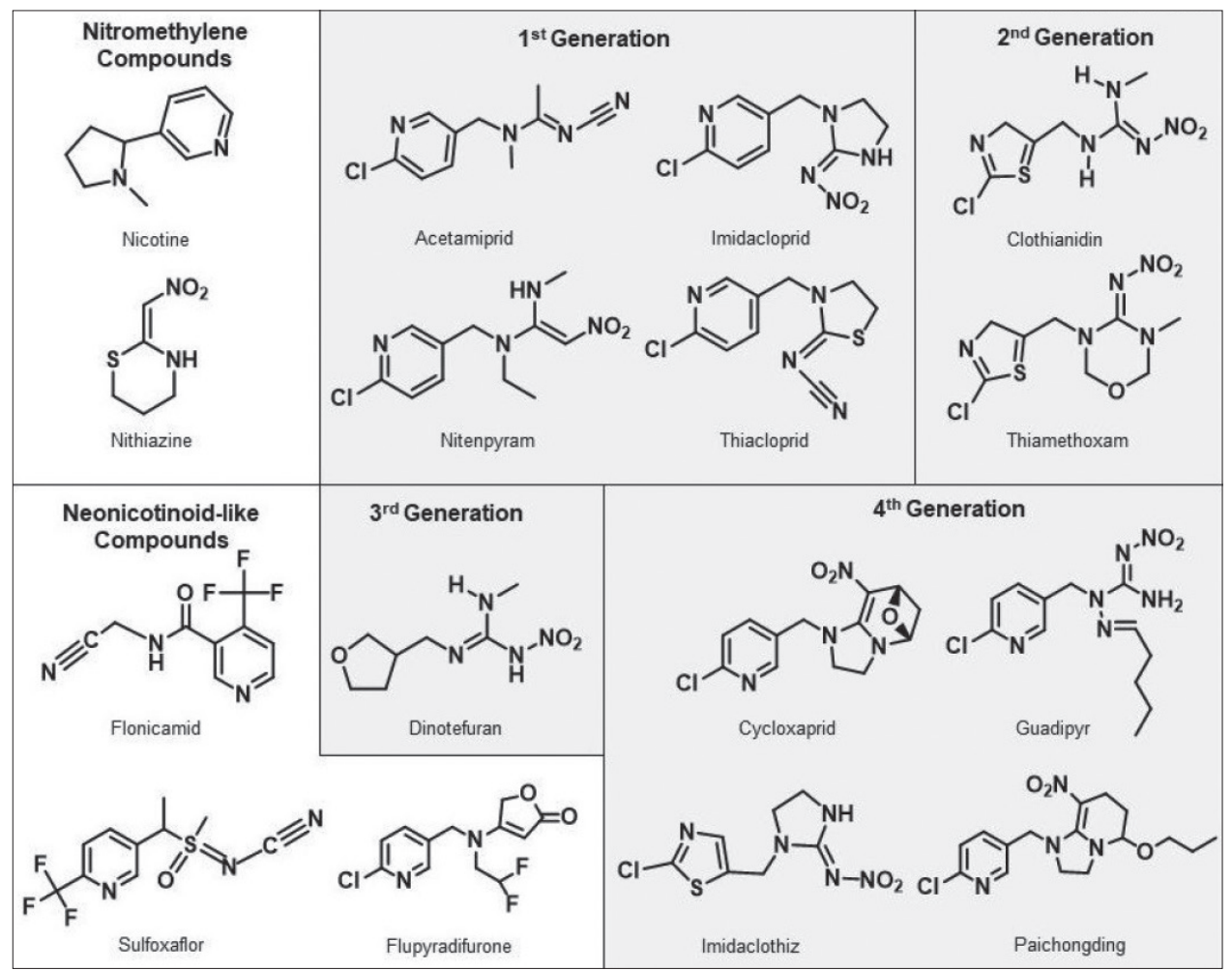

Slika 1. Strukture glavnih predstavnika neonikotinoida (Izvor: Thompson i sur., 2020.) 
kloropiridinski dio, tiametoksam i klotianidin koji sadrže klorotiazolnu skupinu dok dinotefuran posjeduje tetrahidrofuransku funkcionalnu skupinu (Jeschke i sur., 2011.). Dio molekule gdje su vezane razne cijano-, nitro-, amino- ili metilne- skupine odgovoran je za određene biološke i farmakološke interakcije (farmakofori) te utječe na insekticidnu aktivnost, otrovnost i brojna druga fizikalnokemijska svojstva ovih spojeva. Razvoj neonikotinoida temeljen je upravo na traženju heterocikla i farmakofora koji bi dodatno pojačali insekticidnu aktivnost, ali je pritom potrebno voditi računa o optimalnoj raspodjeli elektrona $\mathrm{u}$ farmakoforu potrebnu za vezanje insekticida za receptor i zadržavanju hidrofobnosti neonikotinoida, kako bi uspješno probio kroz zaštitni lipidni omotač koji obavija centralni živčani sustav kukaca (Seifert, 2014.).

Osim sedam glavnih predstavnika ove skupine pesticida još je nekoliko spojeva klasificirano u neonikotinoide: flonikamid, flupiradifuron, sulfoksaflor, gvadipir, cikloksaprida i imidaklotiz (Giorio i sur., 2017.). Dok flupiradifuron i sulfoksaflor imaju vrlo sličan način djelovanja kao i ostali neonikotinoidi, flonikamid se iako ima drugačiji mehanizam djelovanja zbog svoje piridinske strukture također pripisuje ovim pesticidima (Thompsoni sur., 2020.). Kina kao najveći svjetski proizvođač, potrošač i izvoznik neonikotinoida ima glavnu ulogu u razvoju ovih kemijskih tvari.

\section{Mehanizam djelovanja}

Neonikotinoidi u odnosu na ostale klase organskih insekticida posjeduju jedinstvena fizikalna i toksikološka svojstva; općenito imaju najniže log $\mathrm{P}$ vrijednosti (logaritam koeficijenta raspodjele koji opisuje ravnotežu rapodjele otopljenog spoja između vode i organskog otapala koje se ne miješa $\mathrm{s}$ vodom) što je u skladu $\mathrm{s}$ njihovom izvanrednom sistemičnom aktivnošću koju imaju i neki organofosfati i metilkarbamati, ali ne i mnogo lipofilniji organoklorini i piretroidi. S druge strane, neonikotinoidi i piretroidi imaju veći faktor selektivnosti za kukce nego za sisavce $u$ odnosu na organofosfate, metilkarbamate i organoklorine.

Neonikotinoidi su sistemični insekticidi koji u biljci nakon apsorpcije vrlo brzo djeluju, čak i pri niskim dozama, gdje se vaskularnim tkivima prenose kroz korijenje, stabiljku, lišće, cvijeće i plodove (Bonmatin i sur., 2015.). Jednom kad ih kukac proguta, neonikotinoidi se ireverzibilno vežu s nikotinskim acetilkolinskim receptorima (nAChR) i odašilju živčani signal na sličan način kao što to radi i acetilkolin. Acetilkolin esteraza, enzim koji razgrađuju acetilkolin, nije sposoban učiniti isto i $\mathrm{s}$ neonikotinoidima, što pri niskim koncetracijama dovodi do živčane stimulacije i blokade receptora, a pri visokim koncentracijama dovodi do paralize i uginuća kukca (Tomizawa i Casida, 2005.). Nikotin acetilkolinski receptori nisu isključivo u ciljanim štetnicima već ih ima i u kralježnjaka i beskralješnjaka. Pa se tako nAChR nalaze u ljudi u perifernom i u centralnom živčanom sustavu gdje prenose impulse do skeletnih mišića da bi izazvali podražaj, dok u kukaca njihova uloga nije potpuno razjašnjena kao u ljudi, ali su odgovorni i za postsinaptičku neurotransmisiju. Za razliku od sisavaca, ovi receptori se u kukaca nalaze ponajprije u centralnom živčanom sustavu i to $u$ mnogo većem broju. Upravo je to jedan od razloga jače interakcije neonikotinoida i kukaca u odnosu na one s kralježnjacima. Smatra se da su otprilike 5 do 10 puta selektivniji za kukce u odnosu na organofosfate, metilkarbamate i organoklorine. Ta se selektivna toksičnost pripisuje i različitoj osjetljivosti podvrsta nAChR u kukaca i 
kralježnjaka. U kukaca, neonikotinoidi djeluju na najmanje tri različite podjedinice receptora nikotin acetilkolina prouzročujući bifazni učinak.

Neonikotinoidi, u svojoj strukturi, imaju nitro-, cijano- ili ekvivalentni farmakofor, umjesto jednostavno protonirajućeg atoma dušika, što im daje koplanarnu strukturu između tog vrha molekule i supstituiranog gvanidinskog ili amidinskog dijela (Tomizawa i sur., 2003.). Gvanidinski dio molekule imidakloprida ima pKa vrijednosti 1,56 za protonaciju i 11,12 deprotonaciju, što ukazuje na samo $2 \times 10^{-4} \%$ protoniranja pri fiziološkom $\mathrm{pH}$. Ta koplanarnost omogućuje bolje i čvršće vezanje putem konjugiranog elektronskog sustava koji olakšava protok negativnog naboja prema elektronegativnom kraju. Visok afinitet i selektivnost $\mathrm{za}$ receptore kukaca sadržan je u nitrozo $(\mathrm{C}=\mathrm{N}-\mathrm{N}-\mathrm{O})$ analozima neonikotinoida sugerirajući važnost dušika N1 i samo jednog elektronegativnog atoma kisika O1 za neonikotinoidno djelovanje (Slika 2). Udaljenost između dvaju atoma je 5,45-6,06 $\AA$, a N1 atom ima pozitivan parcijalan naboj $(\delta+)$ zbog cijano- ili nitro- supstituenata koji su elektronodvlačeće skupine. Semiempirijskim (PM3) i ab initio izračunima zaključeno je kako taj parcijalni naboj nije izrazit i N1 atom može biti zamijenjen ugljikovim atomom, a da se pritom zadrži afinitet vezanja za receptor kukca i otrovnost insekticida (Zhang i sur., 2004.). Uočeno je da piridin-3-ilmetilni supstituent (ili ekvivalentan) uvelike povećava afinitet vezanja pa se može zaključiti da osim cijano- ili nitro- skupine i dušikovog atoma N1 važan doprinos daje i dušik u pridinskom prstenu.

Ponekad i druge molekulske značajke mogu utjecati na selektivnost pa tako uvođenje azidne $\left(-\mathrm{N}_{3}\right)$ ili amino $\left(-\mathrm{NH}_{2}\right)$ skupine na poziciju 5 u 6-kloropiridin3-ilnim neonikotinoidima rezultira smanjenjem vezanja (Tomizawa i Casida,

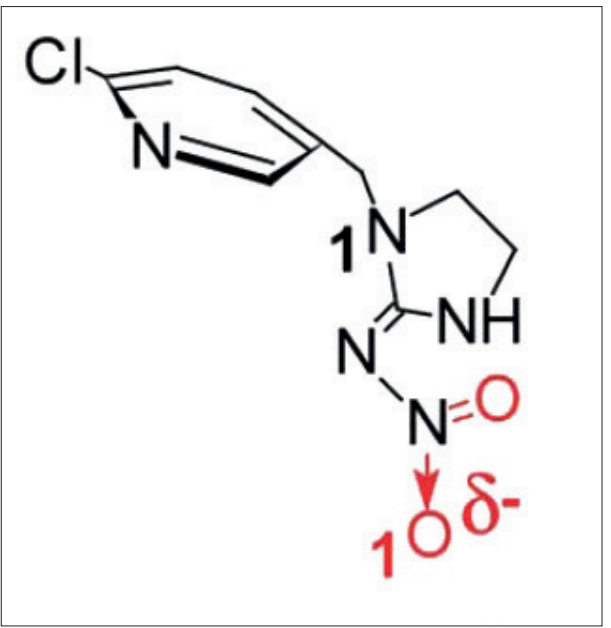

Slika 2. Imidakloprid - elektronegativni dio molekule odgovoran za intenzivno vezanje za receptor kukca (Izvor: Tomizawa i Casida, 2005.)

2005.), N-metilna skupina tiametoksama favorizira određene interakcije receptora pri nižoj temperaturi s ušima u odnosu na muhe dok intenzivnije vezanje kloropiridinilskih neonikotinoida $u$ usporedbi s klorotiazolilnim ovisi o ostatku molekule. Pretpostavlja se kako se elektronegativni farmakofor neonikotinoida veže za pozitivno nabijeni dio nikotin acetilkolinskog receptora kukca (npr. lizin, arginin ili histidin) i iako ne postoje izravni dokazi o stvarnoj poziciji ciljanog dijela molekule, označavanje foto-afiniteta s odgovarajućim neonikotinoidnim ligandom $\mathrm{u}$ kombinaciji $\mathrm{s}$ računalnom simulacijom vezanja može pomoći u određivanju orijentacije elektronegativnog vrha neonikotinoida $u$ aktivnom mjestu receptora.

\section{Primjena i postojanost neonikotinoida u okolišu}

Neonikotinoidisemogu upotrebljavati putem raznovrsnih formulacija i metoda primjene koje su efikasne u suzbijanju širokog spektra štetnika (Simon-Delso 
i sur., 2015.). Granule, natapanje tla, kemigacija ili folijarno prskanje neki su od najčešćih načina korištenja ovih insekticida, među kojima svakako dominira tretiranje sjemena. Često se osim neonikotinoidima sjeme tretira i drugim pesticidima, regulatorima biljnog rasta ili nematicidima kako bi se višestruko osigurao kvalitetan rast biljke i što veći prinos plodova. Svojstva neonikotinoida poput relativno dugog vremena polu-života $u$ tlu i dobre topljivosti u vodi doprinosi postojanosti i prijenosu insekticida u okolišu (Bonmatin i sur., 2015.). Objavljene vrijednosti poluživota za neonikotinoide u tlu kreću se od jednog dana do gotovo 19 godina na što utječe vrsta tla, UV zračenje, vlaga, temperatura i $\mathrm{pH}$. Najčešće se vrlo brzo razgrade, ali u slučaju suhog tla s visokim udjelom organske tvari i pri niskim temperaturama, oni opstaju i potencijalno akumuliraju. S obzirom da su neonikotinoidi dobro topljive molekule $\mathrm{u}$ vodi, objavljeno je i mnogo radova njihovog ustvrđivanja $u$ površinskim i podzemnim vodama. Iako su otporni na hidrolizu pri neutralnom ili kiselom $\mathrm{pH} \mathrm{u}$ anaerobnim uvjetima, uz dovoljnu prisutnost svjetla podložni su brzoj fotodegradaciji, koja se smanjuje povećanjem mutnoće vode (Thompson i sur., 2020.). Razlike u intenzitetu svjetlosti i temperaturi s promjenom zemljopisne širine izravno utječu na vrijeme poluživota po regijama, rezultirajući $s$ porastom vrijednosti udaljavajući se od ekvatora (Bonmatin i sur., 2015.). Do kontaminacije vode može doći raznim putevima i mehanizmima, uključujući pretjerano prskanje, širenje praha milovke i grafita od tretiranog sjemena, površinsko otjecanje, ispiranje $\mathrm{u}$ podzemne vode i topljenjem snijega (Thompson i sur., 2020.). Unatoč sveprisutnosti njihove pojave u vodi, objavljeno je tek nekoliko studija o procjeni rizika izloženosti ljudi neonikotinoidima $u$ vodi za ljudsku potrošnju. Neonikotinoidi, zahvaljujući maloj molekulskoj masi i visokoj topljivosti $\mathrm{u}$ vodi, relativno lako ulaze $\mathrm{u}$ biljna tkiva, gdje se prenose $\mathrm{u}$ pelud, voće i povrće i samim time predstavljaju mogući put izloženosti ljudi jer pranjem ovih namirnica nije moguće $u$ potpunosti ukloniti neonikotinoidne insekticide.

Dva opsežna istraživanja provedena u SAD-u i Kini upućuju da su neonikotinoidi postali sveprisutni $u$ globalnoj opskrbi stanovništva hranom (Lu i sur., 2018.). Dok je američkim istraživanjem ustvrđen barem jedan neonikotinoid u $79 \%$ voća i $65 \%$ povrća, u kineskom istraživanju je uočen jedan ili više neonikotinoida u $57 \%$ voća odnosno $63 \%$ pretraživanog povrća. Tiametoksam (SAD-53 \%; Kina-51 \%) i imidakloprid (SAD-52 \%; Kina-66 \%) bili su najčešće ustvrđeni neonikotinoidni insekticidi u oba istraživanja. Romeh i sur. (2009.) ispitivali su postojanost imidakloprida $u$ uzorcima rajčica, gdje su zaključili kako je moguće mehanički (pranjem, guljenjem kože) ukloniti barem dio neonikotinoida (7-30\%), dok su i preradom rajčica dobili niže vrijednosti rezidua.

Shodno prisutnosti i postojanosti $u$ svim navedenim okolišnim uzorcima neonikotinoidi predstavljaju ozbiljnu prijetnju očuvanju pčelinjih zajednica, koje dolaze $\mathrm{u}$ izravan kontakt $\mathrm{s}$ njima putem onečišćenog peluda, nektara ili vode jer već pri vrlo niskim koncentracijama mogu prouzročiti poremećaje u njihovom ponašanju i orijentaciji, a pri višim i uginuće (Tlak Gajger i sur., 2016., 2017.). Rezidue neonikotinoida pronađeni su u zrncima peluda, $u$ fermentiranom peludu pohranjenom u saću, $u$ zrelom medu te $u$ vrcanom medu kao finalnom proizvodu što dovoljno govori o otpornosti i stabilnosti ovih insekticida.

\section{Metabolizam i toksičnost}

Da bi se procijenila potencijalna opasnost po zdravlje ljudi i životinja vrlo je važno proučiti glavne transformacijske 
puteve neonikotinoida i proizvode koji nastaju u okolišu, uglavnom metaboličkim i fotokemijskim reakcijama. Ovim procesima, ovisno o mehanizmu nastajanja, mogu nastati identični ili različiti proizvodi. U većini slučajeva do promjenjene bioaktivnosti dolazi uslijed transformacija cijano- i nitrofunkcionalnih skupina (farmakofora) koje su bogate elektronima. Nitro skupina se može transformirati prvo u desnitro gvanidinski metabolit, a potom u urejski metabolit (Thompson i sur., 2020.). Desnitro oblik je zbog raspodjele pozitivnog naboja na gvanidinu koji spremno reagira $s \mathrm{nAChR}$ sisavaca bitno otrovniji za kralježnjake. Cijanofunkcionalna skupina se čini dosta stabilnija od nitro- skupine što je primjerice vidljivo kod fotolize gdje za razliku od tiametoksama, imidakloprida i klotianidina (nitro-neonikotinoidi) kod kojih dolazi do fotodegradacije molekula, cijano-neonikotionidi - acetamiprid i tiakloprid, su na sunčevoj svjetlosti stabilni.

Moguće su metaboličke pretvorbe i na drugim strukturnim dijelovima neonikotinoida koje rezultiraju promjenama u toksičnosti i insekticidnoj aktivnostipajetakouočenodajeoksidacija nitrometilenskog ugljika kod nitiazina vrlo vjerojatno mehanizam koji dovodi do smanjenja toksičnosti (Tomizawa i Casida, 2005.). Hidroliza imidakloprida se provodi na jednom od dva metilenska supstituenta $\mathrm{u}$ imidazolidinskom dijelu molekule, nakon čega slijedi formiranje olefina konjugacijom ili dehidratacijom uz minimalno ili bez otvaranja prstena, a pritom ostaje zadržan potencijal vezanja za nAChR kukca. Praćenjem N-demetilacije nekih neonikotionida (imidakloprid, nitenpiram, tiaametoksam) uočena je povećana insekticidna $\mathrm{i} / \mathrm{ili}$ receptorska aktivnost. Tiametoksam se jednostavno prevodi u klotianidin hidroksilacijom metilenske skupine $\mathrm{u}$ prstenu $\mathrm{u}$ kukaca i biljaka, pri čemu klotianidin podliježe $N$-demetilaciji. Kod tiakloprida dolazi do otvaranja tiazolidinskog prstena, a atom sumpora se potom oksidira i metilira. Acetamiprid uz $N$-demetilaciju ima i cijepanje veze s $N$-cijanoacetamidom u biljkama. Kod dinotefurana, hidroksilacija tetrahidrofuranskog dijela dovodi do otvaranja prstena i oslobađanja aldehida koji tvori ciklizirane derivate. Nitrogvanidinska $\left(\mathrm{C}=\mathrm{N}-\mathrm{NO}_{2}\right)$ polovina imidakloprida se reducira do nitrozogvanidina $(\mathrm{C}=\mathrm{N}$ $\mathrm{NO})$ i aminogvanidina $\left(\mathrm{C}=\mathrm{N}-\mathrm{NH}_{2}\right)$, a cijepanjem nastaju gvanidinski $(\mathrm{C}=\mathrm{NH}) \mathrm{i}$ ureja $(\mathrm{C}=\mathrm{O})$ derivati. Nitrozogvanidinski metabolit imidakloprida posjeduje jaku insekticidnu aktivnost za razliku od gvanidinskog metabolita koji pokazuje potentno djelovanje samo za sisavce. Hidrolizom $\mathrm{C}=\mathrm{N}-\mathrm{CN}$ strukturne jedinice tiakloprida nastaje amid $\mathrm{C}=\mathrm{NC}(\mathrm{O}) \mathrm{NH}_{2}$, a nakon toga se također cijepa veza $\mathrm{N}-\mathrm{CN}$. Descijanotiakloprid jest osobito potentan agonist $\mathrm{nAChR}$ sisavaca.

Kloropiridinilmetilni, klorotiazolilmetilni i tetrahidrofuranmetilni supstituenti podliježu hidroksilaciji $N$-metilenske skupine i cijepanju, nakon toga se oksidacijom aldehida prevode do karboksilnih kiselina (6-kloronikotinska kiselina, 2-kloro-1,3-tiazol-5-karboksilna kiselina i 3-furoična kiselina) koje se nakon konjugacije s glicinom ili glukuronskom kiselinom putem urina u sisavaca zbog svoje male molekulske mase i dobre topljivosti u vodi izlučuju (Thompson i sur., 2020.).

Neonikotinoidi i njihovi metaboliti dugotrajno opstaju u okolišu te mogu djelovati sinergistički zajedno s fungicidima, što im povećava otrovnost za 1000 puta (Tlak Gajger i sur., 2016.). Mapiranjem cjelokupnog genoma pčela otkriveno je da receptori nikotin acetilkolina imaju 11 podjedinica $u$ njihovom živčanom sustavu, što je mnogo više nego $u$ komarca ili vinske mušice i samim time je neurotoksičan učinak 
neonikotinoida i njihovih metabolita mnogo jači.

Otrovnost neonikotinoida ovisi i o načinu izlaganja pa je tako Cresswell (2011.) u meta-analizi iz 2011. godine o učincima djelovanja imidakloprida na 7073 odraslih pčela i 36 zajednica u laboratorijskim i polu-kontroliranim uvjetima u pčelinjaku prikazao kako in vivo istraživanje na otvorenom nije imalo smrtonosne učinke pri primjenjivanim dozama, ali je ipak rezultiralo smanjenim učinkom pčela za 6 do $20 \%$. S druge strane, Blacquière i sur. (2012.) u svom preglednom radu opisuju laboratorijska istraživanja gdje su uočeni smrtonosni i subletalni učinci na prikupljanje hrane te sposobnost učenja i pamćenja u pčela. Kako ovi učinci istraživanjima na terenu nisu dokazani, brojni radovi sugeriraju kako nije moguće potvrditi isključivi utjecaj uporabe neonikotinoida na život pčela zbog jednostranog promatranja problema i nedostatka pouzdanih informacija o ranijim pojavama pomora pčela prije globalne uporabe ovih insekticida (Majdančić i sur., 2017.). Većina laboratorijskih istraživanja fokusira se na utjecaj neonikotinoida na pojedine jednike pčela, iako učinci djelovanja mogu biti drugačiji ukoliko se pčelinja zajednica promatra u cjelini. Osim utjecaja vanjskih čimbenika potrebno je uzeti u obzir i utjecaj populacije pčelinjih zajednica izražen kroz promjenu odnosa broja trutova i radilica u pojedinim razdobljima razvoja i proizvodnosti jer se ovaj odnos ovisno o stanju paše i raspoloživosti prirodne hrane dinamično mijenja.

Toksičnost aktivnih tvari neonikotinoida za pčele mjeri se vrijednošću $\mathrm{LD}_{50}\left(\right.$ letalna doza $\left.{ }_{50}\right)$ i/ili LC $_{50}$ (letalna koncentracija ${ }_{50}$ ) koje se određuju na osnovu ustvrđenog broja uginulih pčela nakon 24 do 48 sati po primjeni pojedinog neonikotinoida, međutim oralne $\mathrm{LD}_{50}$ se razlikuju u raznim istraživanjima (Tlak Gajger i sur., 2017.).

\section{Određivanje rezidua} neonikotinoida u pčelama $i$
pčelinjim proizvodima

Zbog svojstava i velike uporabe diljem svijeta, za očekivati je da će se jednom kada se apliciraju na biljke neonikotinoidi moći ustvrditi i u okolišu. Iz tog razloga, potrebno je procijeniti distribuciju neonikotinoida u okolini kako bi se dobio bolji uvid u razinu rizika koji oni predstavljaju za pčele i ostale kukce oprašivače. Da bi se istražila izloženost pčela pesticidima svakako je potrebno razvijanje prikladnih metoda određivanja njihovih rezidua, kako u pčeli tako i u pčelinjim proizvodima. Analizu ovih insekticida otežava raznolikost i složenost vrsta uzoraka koje je potrebno analizirati $\mathrm{u}$ niskim koncentracijama u kojima su obično prisutni. U tu svrhu laboratoriji moraju imati razvijenu i implementiranu multirezidualnu analitičku metodu za simultano određivanje što većeg broja aktivnih supstanci koje najčešće posjeduju raznolika fizikalno-kemijska svojstva. Samu metodologiju određivanja karakterizira širok spektar analita različitih polarnosti, topljivosti, $\mathrm{pKa}$ vrijednosti, koncentracijskih razina te različite vrste uzoraka koje utječu na pojedine analite zbog razlika $\mathrm{u}$ udjelu vode, masti i biokemijskog sastava (Knežević i sur., 2010.). Postupci određivanja uključuju homogenizaciju uzorka s organskim otapalom ili smjesom organskog otapala, s vodom sa ili bez podešavanja $\mathrm{pH}$ vrijednosti uporabom homogenizatora ili ultrazvučnih miješalica, potom slijedi ekstrakcija spojeva iz uzoraka, pročišćavanje ekstrakta i kvantitativno određivanje analita primjenom kromatografskih tehnika.

Ekstrakcija na čvrstom nosaču (engl. Solid-phase extraction, SPE) jest najčešće korištena metodologija za ekstrakciju i pročišćavanje neonikotinoidnih pesticida 
u pčelinjim proizvodima. Ciljani se analiti otopljeni u ekstrakcijskom otapalu nanose se na SPE kolonu, vežu za nepokretnu fazu, a potom se kako bi se uklonile interferirajuće tvari kolona ispire u odgovarajućim otapalima. Analiti se prikupe eluiranjem kolone otapalom $\mathrm{u}$ kojem su dobro topljivi. Schöning i Schmuck (2003.) prvi su upotrijebili SPE kolone punjene dijatomejskom zemljom za pročišćavanje uzoraka meda prilikom određivanja imidakloprida i dva metabolita (5-hidroksi- i olefin imiakloprid). Nakon eluiranja s diklormetanom (DCM), sadržaj je dodatno počišćen na koloni sa silikagelom, ispran smjesom otapala toluen-etil acetat te eluiran $\mathrm{s}$ acetonitrilom (ACN). Detekcija je provedena tekućinskom kromatografijom spregnutom s tandemnom spektrometrijom masa (LCMS/MS pri čemu su postignute granice kvantifikacije od $5-10 \mu \mathrm{g} / \mathrm{kg}$.

Postoji nekoliko vrsta SPE kolona punjenih različitim sorbensima koje se danas standardno koriste prilikom određivanja rezidua neonikotinoida, kao što su Strata C18, Oasis HLB, Strata-X i Strata X-CW. Upravo su ovu zadnju varijantu izabrali Gbylik-Sikorska i sur. (2015.) u svom radu gdje su određivali sedam neonikotinoida $i$ šest njihovih metabolita u medu, dok su prilikom analize uzoraka pčela supernatant nakon ekstrakcije profiltrirali preko Sep-Pak Alumina N Plus Long patrona. $\mathrm{Za}$ eluaciju je korištena smjesa otapala ACN i etil acetata $(8: 2, \mathrm{v} / \mathrm{v})$ koja se potom uparila u struji dušika, a suhi ostatak je otopljen u minimalnoj količini vode prije LC-MS/MS analize. Za sve obuhvaćene analite granice kvantifikacije su se kretale u području 0,1 do $0,5 \mu \mathrm{g} / \mathrm{kg}$, a dobiveni su ostatci od 89 do $112 \%$, zadovoljavajući kriterije SANTE dokumenta (2019.) (70$120 \%)$.

Hou i sur. (2019.) su osim meda analizirali i uzorke matične mliječi koju izlučuju mlade pčele radilice. Uzorci su ekstrahirani smjesom metanola $(\mathrm{MeOH})$ i vode $\left(\mathrm{H}_{2} \mathrm{O}\right)$, a nakon postupka centrifugiranja kako bi se istaložile bjelančevine, koje čine više od četvrtine suhe tvari matične mliječi, supernatant se nanio na Oasis HLB kolone. Kolone su isprane smjesom $\mathrm{MeOH}: \mathrm{H}_{2} \mathrm{O}$ (1:9, $\mathrm{v} / \mathrm{v})$, a zatim su ciljani analiti eluirani čistim $\mathrm{MeOH}$ u staklene epruvete te nakon uparavanja do suhog, ekstrakt je rekonstituiran u metanol/0,15\% mravlja kiselina $(1: 9, \mathrm{v} / \mathrm{v})$ i analiziran LC-MS/MS tehnikom. Dobiveni su zadovoljavajući ostatci $(72,8-106,5 \%)$ i preciznost (RSD $<13,8 \%$ ) za sve analite.

Važan matriks za procjenu izloženosti pesticidima svakako je pčelinji vosak koji se u pčelarskoj praksi uobičajeno reciklira i u kojem je vrlo vjerojatna akumulacija okolišnih onečišćivača (Tlak Gajger i sur., 2019.). Uglavnom se sastoji od uglijkovodika i estera te ima točku tališta na otprilike $65{ }^{\circ} \mathrm{C}$ što ga čini posebno zahtjevnim matriksom za razvijanje pouzdane i osjetljive analitičke metode. Yáñez i sur. (2013.) su opisali razvijanje jedne takve metode. Istaknuli su kako je vrlo važno prilikom obogaćivanja neonikotinoidima zagrijati vosak na temperaturu od $70{ }^{\circ} \mathrm{C}$ kako bi se zadržala homogenost uzoraka. Za njihovo otapanje koristila se smjesa heksana i izopropanola $(8: 2, \mathrm{v} / \mathrm{v})$, pri čemu je izopropanol dodan radi bolje ekstrakcije neonikotinoida. Potom se dodaje voda $\mathrm{u}$ svrhu razdijeljenja i ekstrakciju analita u vodeni sloj. Nakon što se vodeni ekstrakt nanese na SPE kolone s dijatomejskom zemljom, eluacija se provodi s acetonom jer se tim otapalom dobivaju najbolji ostatci, a i vrlo jednostavno ga je upariti. Za uzorke u kojima se određuje veći broj neonikotinoidnih metabolita, pokazalo se kako je bolja opcija koristiti SPE kolone s C18 sorbensom umjesto slabog anionskog izmjenjivača koji sadrži i primarne i sekundarne amine (PSA). U tom slučaju, dodatak trietilamina $\mathrm{u}$ otapalo kojim se eluira, najčešće $A C N$, pospješuje 
desorpciju metabolita s C18 kolona (Kamel, 2010.). PSA sorbens se uobičajeno koristi u koraku disperzivne ekstrakcije na čvrstom nosaču (d-SPE) QuEChERS metode za ko-ekstrakciju interferirajućih tvari iz matriksa, ponajviše šećera. Kod QuEChERS protokola, u prvom koraku se dodavaju soli, uglavnom $\mathrm{MgSO}_{4}$ i $\mathrm{NaCl}$, u uzorak koji se ekstrahira smjesom ACN i vode kako bi se potaknulo razdvajanje slojeva. Tu i Chen (2020.) su u svom preglednom radu analitičkih metoda za određivanje neonikotinoidnih pesticida u pčelama i pčelinjim proizvodima opisali nekoliko studija koje su koristeći razne modifikacije QuEChERS tehnike dobili vrlo zadovoljavajuće rezultate. Primijećeno je kako se dodatkom i citratnih soli $\mathrm{u}$ prvom koraku dobivaju veći ostatci neonikotinoida, uz kvalitetnije kromatografsko razdvajanje i rezoluciju pikova na LC-MS/MS instrumentu.

Uspoređujući $\mathrm{NaCl}$ s NaOAc nisu uočene velike razlike kod određivanja imidakloprida, njegovih metabolita te klotianidina, no u slučaju ostalih neonikotinoida, acetat se pokazao kao bolji odabir u svrhu isoljivanja. Uzorci iz košnice koji sadrže veću količinu lipidnih tvari, poput peluda i pčela, zahtijevaju dodatan korak pročišćavanja, u svrhu minimiziranja matričnog efekta pa se to najčešće provodi ektrakcijom tekuće-tekuće n-heksanom ili DCM-om, no najbolji rezultati su zabilježeni tzv. freeze-out postupkom gdje se nadtalog stavlja u posudu sa suhim ledom ili u zamrzivač radi taloženja lipida i proteina. Iako je mnogo analitičkih tehnika (ELISA, plinska kromatografija, kapilarna elektroforeza, superkritična fluidna kromatografija) primjenjivano za analizu neonikotinoidnih ineskticida, tekućinska kromatografija uporabom C8 i C18 kolona obrnutih faza je svakako najprikladniji odabir za separaciju ovih tvari, uzimajući u obzir njihova fizikalnokemijska svojstva poput visoke polarnosti i niske hlapljivosti (Valverde i sur., 2016.).
Iako su objavljivani radovi $\mathrm{s}$ DAD detekcijom, masena spektormetrija (primarno tandemna - trostruki kvadrupol, QqQ) zbog veće selektivnosti i osjetljivosti najčešće je upotrebljavan detektor $\mathrm{u}$ metodama određivanja neonikotinoida, čijom se uporabom dobivaju granice kvantifikacije $u$ ppb (engl. parts per billion) području $\mathrm{s}$ prihvatljivim iskorištenjem i RSD vrijednostima (Tu i Chen, 2020.). Zbog jedinstvenih karakteristika brzog načina rada i sposobnosti visokog razlučivanja, TOF i Orbitrap analizatori masa su također korišteni za određivanje neonikotinoida. Zaključeno je da usprkos dobivanju nešto viših granica kvantifikacija u odnosu na QqQ, navedena tehnologija, je zahvaljujući, vrlo preciznim izračunima masa idealan alat za određivanje neciljanih metabolita.

\section{Literatura}

1. ABDOLLAHI, M., A. RANJBAR, S. SHADNIA, S. NIKFAR and A. REZAIE (2004): Pesticides and oxidative stress: a review. Med. Sci. Monit. 10, RA141-147.

2. BLACQUIÈRE, T., G. SMAGGHE, C. A VAN GESTEL and V. MOMMAERTS (2012): Neonicotinoids in bees: a review on concentrations, side-effects and risk assessment. Ecotoxicology 21, 973-992.

3. BONMATIN, J.M., C.GIORIO, V.GIROLAMI, et al. (2015): Environmental fate and exposure; neonicotinoids and fipronil. Environ. Sci. Pollut. Res. Int. 22, 35-67.

4. CHAUZAT, M.-P., P. CARPENTIER, A.-C MARTEL, S. BOUGEARD, N. COUGOULE, P. PORTA, J. LACHAIZE, F. MADEC, M. AUBERT and J.-P. FAUCON (2009): Influence of pesticide residues on honey bee (Hymenoptera: Apidae) colony health in France. Environ. Entomol. 38, 514-523.

5. CRESSWELL, J. E. (2011): A meta-analysis of experiments testing the effects of a neonicotinoid insecticide (imidacloprid) on honey bees Ecotoxicology 20,149-157.

6. EC (2013): Commission implementing regulation (EU) No 485/2013 of 24 May 2013 amending Implementing Regulation (EU) No 540/2011, as regards the conditions of approval of the active substances clothianidin, thiamethoxam and imidacloprid, and prohibiting the use and sale of seeds treated with plant protection products containing those active substances. Off. J. Eur. Commun. L139, 12-26. 
7. EC (2018a): Commission implementing regulation (EU) 2018/783 of 29 May 2018 amending Implementing Regulation (EU) No 540/2011 as regards the conditions of approval of the active substance imidacloprid. Off. J. Eur. Commun. L132, 31-34.

8. EC (2018b): Commission implementing regulation (EU) 2018/784 of 29 May 2018 amending Implementing Regulation (EU) No 540/2011 as regards the conditions of approval of the active substance clothianidin. Off. J. Eur. Commun. L132, 35-39.

9. EC (2018c): Commission implementing regulation (EU) 2018/785 of 29 May 2018 amending Implementing Regulation (EU) No 540/2011 as regards the conditions of approval of the active substance thiamethoxam. Off. J. Eur. Commun. L132, 40-44.

10. EC (2018d): Commission implementing regulation (EU) 2018/113 of 24 January 2018 renewing the approval of the active substance acetamiprid in accordance with Regulation (EC) No 1107/2009 of the European Parliament and of the Council concerning the placing of plant protection products on the market, and amending the Annex to Commission Implementing Regulation (EU) No 540/2011. Off. J. Eur. Commun. L20, 7-10.

11. EFSA (2019): Peer review of the pesticide risk assessment of the active substance thiacloprid. EFSA Journal 17, 5595.

12. GBYLIK-SIKORSKA, M., T. SNIEGOCKI and A. POSYNIAK (2015): Determination of neonicotinoid insecticides and their metabolites in honey bee and honey by liquid chromatography tandem mass spectrometry. J. Chromatogr. B 990, 132-140.

13. GIORIO, C., A. SAFER, F. SÁNCHEZ-BAYO, A. TAPPARO, A. LENTOLA, V. GIROLAMI, M. B. VAN LEXMOND and J.-M. BONMATIN (2017): An update of the worldwide integrated assessment (WIA) on systemic insecticides. Part 1: new molecules, metabolism, fate, and transport. Environ. Sci. Pollut. Res. 28,11716-11748.

14. HOU, J., W. XIE, D. HONG, W. ZHANG, F. LI, Y. QIAN and C. HAN (2019): Simultaneous determination of ten neonicotinoid insecticides and two metabolites in honey and Royaljelly by solid-phase extraction and liquid chromatography-tandem mass spectrometry. Food Chem. 270, 204-213.

15. IWASA, T., N. MOTOYAMA, J. AMBROSE and R. M. ROE (2004): Mechanism for the differential toxicity of neonicotinoid insecticides in the honey bee. J. Crop Prot. 23, 371-378.

16. JABŁOŃSKA-TRYPUĆ, A. (2017): Pesticides as inducers of oxidative stress. React. Oxyg. Species 3, 96-110.

17. JESCHKE, P., R. NAUEN, M. SCHINDLER and A. ELBERT (2011): Overview of the status and global strategy for neonicotinoids. J. Agric. Food Chem. 59, 2897-2908.

18. JOHNSON, R. M., M. D. ELLIS, C.A. MULLIN and M. FRAZIER (2010): Pesticides and honey bee toxicity - USA*. Apidologie 30, 235-248.

19. KAMEL, A. (2010): Refined methodology for the determination of neonicotinoid pesticides and their metabolites in honey bees and bee products by liquid chromatography-tandem mass spectrometry (LC-MS/MS). J. Agric. Food Chem. 58, 5926-5931.
20. KNEŽEVIĆ, Z., N. BILANDŽIĆ, M. ĐOKIĆ i M. SEDAK (2010): Sigurnost hrane i pesticidi. Vet. stn. 41, 303-309.

21. KRUPKE, C. H., G. J. HUNT, B. D. EITZER, G. ANDINO and K. GIVEN (2012): Multiple routes of pesticide exposure for honeybees living near agricultural fields. PLoS ONE 7(1), e29268.

22. LONARE, M., M. KUMAR, S. RAUT, P. BADGUJAR, S. DOLTADE and A. TELANG (2014): Evaluation of imidacloprid-induced neurotoxicity in male rats: A protective effect of curcumin. Neurochem. Int. 78, 122-129.

23. LU, C., C.-H. CHANG, C. PALMER, M. ZHAO and Q. ZHANG (2018): Neonicotinoid residues in fruits and vegetables: An integrated dietary exposure assessment approach. Environ. Sci. Technol. 52, 3175-3184.

24. LUSHCHAK, V. I., T. M. MATVIISHYN, V. V. HUSAK, J. M. STOREY and K. B. STOREY (2018): Pesticide toxicity: a mechanistic approach EXCLI. J. 17, 1101-1136.

25. MAJDANČIĆ, M., B. MUHIĆ i M. BAŠIĆ (2017): Utjecaj neonikotinoida na pčelarstvo. Zbornik radova i sažetaka sa drugog kongresa o pčelarstvu i pčelinjim proizvodima sa međunarodnim učešćem - Pčelarstvo i pčelinji proizvodi $2,54-62$.

26. PHUA, D. H., C. C. LIN, M. L. WU, J. F. DENG and C. C. YANG (2009): Neonicotinoid insecticides: an emerging cause of acute pesticide poisoning. Clin. Toxicol. (Phila). 47, 336-341.

27. POTTS, S. G., J. C. BIESMEIJER, C. KREMEN, P. NEUMANN, O. SCHWEIGER and W.E. KUNIN (2010): Global pollinator declines: trends, impacts and drivers. Trends Ecol. Evol. 25, 345-353.

28. RASZEWSKI, G., M. K. LEMIESZEK, K. ŁUKAWSKI, M. JUSZCZAK and W. RZESKI (2015): Chlorpyrifos and cypermethrin induce apoptosis in human neuroblastoma cell line $\mathrm{SH}-$

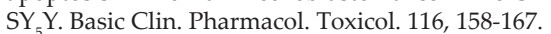

29. ROMEH, A. A., T. M. MEKKY, R. A. RAMADAN and M. Y. HENDAWI (2009): Dissipation of profenofos, imidacloprid and penconazole in tomato fruits and products. Bull. Environ. Contam. Toxicol. 83, 812.

30. SANTE (2019): Guidance SANTE/12682/2019 Guidance document on analytical quality control and method validation procedures for pesticides residues analysis in food and feed.

31. SCHÖNING, R. and R. SCHMUCK (2003): Analytical determination of imidacloprid and relevant metabolite residues by LC MS/MS. B. Insectol. 56, 41-50.

32. SEIFERT, J. (2014): Neonicotinoids. Encyclopedia of Toxicology (Third Edition). 477-482.

33. SIMON-DELSO, N., V. AMARAL-ROGERS, L. P. BELZUNCES, et al. (2015): Systemic insecticides (neonicotinoids and fipronil): trends, uses, mode of action and metabolites. Environ. Sci. Pollut. Res. 22, 5-34.

34. STOKSTAD, E. (2013): Pesticides under fire for risks to pollinators. Science 340 (6133), 674-676.

35. THOMPSON, D. A., H. J. LEHMLER, D. W. KOLPIN, et al. (2020): A critical review on the potential impacts of neonicotinoid insecticide use: 
current knowledge of environmental fate, toxicity, and implications for human health. Environ. Sci. Process Impacts. 22, 1315-1346.

36. TLAK GAJGER, I., I. BOSEK, N. BILANDŽIĆ i M. KOSANOVIĆ (2016): Utjecaj neonikotinoida na kukce opašivače. Vet. stn. 47, 353-363.

37. TLAK GAJGER, I., M. SAKAČ and A. GREGORC (2017): Impact of thiamethoxam on honey bee qeeen (Apis mellifera) reproductive morphology and physiology. Bull. Environ. Contam. Toxicol. 99, 3, 297-302.

38. TLAK GAJGER, I., M. KOSANOVIĆ, V. OREŠČANIN, S. KOS and N. BILANDŽIĆ (2019): Mineral content in honeybee wax combs as a measurement of the impact of environmental factors. Bull. Environ. Contam. Toxicol. 103, 697-703.

39. TOMIZAWA, M., N. ZHANG, K.A.DURKIN, M. M. OLMSTEAD and J. E. CASIDA (2003): The neonicotinoid electronegative pharmacophore plays the crucial role in the high affinity and selectivity for the Drosophila nicotinic receptor: an anomaly for the nicotinoid cation- $\pi$ interaction model. Biochemistry 42, 7819-7827.

40. TOMIZAWA, M. and J. E. CASIDA (2005) Neonicotinoid insecticide toxicology: mechanisms of selective action. Annu. Rev. Pharmacol. Toxicol. 45, 247-268.

41. TU, X. and W. CHEN (2020): Overview of analytical methods for the determination of neonicotinoid pesticides in honeybee products and honeybee. Crit. Rev. Anal. Chem. 19, 1-10.

42. VALVERDE, S., J. L. BERNAL, M. T. MARTÍN, M. J. NOZAL and J. BERNAL (2016): Fast determination of neonicotinoid insecticides in bee pollen using QuEChERS and ultra-high performance liquid chromatography coupled to quadrupole time-of-flight mass spectrometry. Electrophoresis 37, 2470-2477.

43. YÁÑEZ, K. P., J. L. BERNAL, M. J. NOZAL, M. T. MARTIN and J. BERNAL (2013): Determination of seven neonicotinoid insecticides in beeswax by liquid chromatography coupled to electrospray-mass spectrometry using a fused-core column. J. Chromatogr. A 1285, 110-117.

44. ZHANG, N., M. TOMIZAWA and J. E. CASIDA (2004): $\alpha$-Nitro ketone as an electrophile and nucleophile: synthesis of 3-substituted 2- nitromethylenetetrahydrothiophene and -tetrahydrofuran as Drosophila nicotinic receptor probes. J. Org. Chem. 69, 876-881.

\section{Use of neonicotinoids and monitoring of its residues in honeybees and honeybee products}

Damir PAVLIČEK, M.Chem, Croatian Veterinary Institute, Veterinary Department Križevci, Križevci, Croatia; Nina BILANDŽIĆ, BSc, PhD, Scientific Advisor, Croatian Veterinary Institute, Zagreb, Croatia; Ivana TLAK GAJGER, DVM, Full Professor, Faculty of Veterinary Medicine University of Zagreb, Croatia; Marija DENŽIĆ LUGOMER, BSc, Croatian Veterinary Institute, Veterinary Department Križevci, Križevci, Croatia

The use of pesticides in agricultural cropping systems is often associated with mass extinction or population declines in honeybee colonies due to poisoning. Over the past 20 years, neonicotinoid pesticides have become the most widely used class of insecticides due to their high toxicity for insects but low toxicity to vertebrates, and high efficacy and systemic activity in plants. The basic structure consists of either a nitromethylene, nitroimine, or cyanoimine functional group, while their prime member is imidacloprid, the second most used pesticide in the world after glyphosate. By mode of action, neonicotinoids are considered agonists on the postsynaptic nicotinic acetylcholine receptor of the insect's central nervous system, causing a blockage of signal transmission, resulting in disorientation, paralysis or even death. Residues of neonicotinoids can be present in plant pollen and nectar, the main natural food source that honeybees collect and store in hives. Numerous studies have demonstrated that concentrations of these insecticides have a negative effect on honeybee health and behaviour. In response to this concern, these substances have been subject to a peer review of the pesticide risk assessment, resulting in the prohibition by the European Commission of the use of clothianidin, imidacloprid, thiamethoxam and thiacloprid for all outdoor uses in Member States, with the exception of greenhouses. This review paper provides insight into the main properties of neonicotinoids, the development and implementation of reliable analytical methods for determination of their residues in honeybees and bee products, and the challenges faced due to the complex matrices that contain beeswax, proteins and other interfering compounds.

Key words: neonicotinoids; honeybee; toxicity; residues 